\title{
Territorial connection and cohesion. The case of Agrigento inland area
}

\author{
Gerlandina Prestia $^{1, a}$, Valeria Scavone ${ }^{2, b}$ \\ ${ }^{1}$ Viale delle Scienze, ed. 14, 90128 Palermo \\ ${ }^{2}$ Viale delle Scienze, ed. 14, 90128 Palermo \\ ${ }^{3}$ Viale delle Scienze, ed. 8, 90128 Palermo \\ agerlandina.prestia@unipa.it, ${ }^{b}$ valeria.scavone@unipa.it
}

Keywords: territorial cohesion, inland areas, connections, depopulation

\section{Introduction}

The Europe 2020 strategy and the Horizon 2020 program can begin a real path about the role that the city will be able play for a new development. New development because, if in a not too distant past, the term development, associated with the city, it referred to the expansion of the city-for a better living conditions and in the illusion of achieving a quality urban- now, development must be understood rather as growth, in relation to cities ability to be resilient to the current crisis. The EU turns his attention to the city, as evidenced by the proposal (2012) for a new Regulation of the European Fund for Regional Development (ERDF) for «sustainable urban actions» provided for by the Europe 2020 strategy. This document provides for that $5 \%$ of the resources allocated at national level should be set to «Integrated actions for sustainable urban development», delegated to cities. Therefore, the creation of financial instruments for Research and Innovation in Europe, is not a completely new and the Horizon 2020 is an driving of the wider Europe 2020 strategy. The aim of this strategy is to propose a model of development for Europe, which aims to raise levels of employment, productivity and social cohesion through a process of structuring smarter, sustainable and inclusive [1].

Usually, it is in the cities that are intensifying tangible and intangible social relations and, given that they focused almost $70 \%$ of the world population, it is clear that the city must begin to start any development scenario: the problems / opportunities related to the management of natural resources, energy to move. Can not think of anything without exceeding a fragmented and sectoral management of the problems of urban areas; without a strategic approach towards the rethinking of the relationship between functional and economical small urban realities, away from the pole, but that may be the heritage of pole for the soil, water, landscape and agricultural production. These small urban realities are the inland area.

The small cities- 5683 on 8093 Italian municipalities [2]- are often «settlements located in areas not easily accessible (...) areas subject to depopulation»[3] have grown, for centuries, over themselves, creating complex layers within the building heritage which await a discovery to learn about the culture and the civilization from which they originated and which have governed the transformation processes. The culture is a «primary factor of urban creativity (...), the city's identity that has its roots the program schedule of history and extends its branches in the future» [4], awaiting a new model of development local self-sustainable combining protection, conservation, enhancement of resources and economic recovery.

\section{Inland areas in the Italian reality: Sicily and the case of Agrigento}

In Italy, the theme inland areas has been recently addressed the Ministry of Economic Development, Department for Development and Economic Cohesion, during a seminar (15 December 2012) about new strategies for the 2014-2020, programming of regional policy. The inland Areas are about 3/5 of the territory and a little less than 1/4 of the population; they are diversified areas, away from the poles (centers offer services) and development trajectories unstable 
but, nevertheless, with sufficient resources that are missing the central areas; «rough with demographic problems but also strongly polycentric and with strong potential to attract».

The classification made by the DPS separates the inland areas in outermost area, peripheral area and intermediate area. The level of peripherality is based on distance thresholds (computed in minutes) of the different areas from the nearest pole: outerrmost $\mathrm{t}>75$ '; peripheral $40^{\prime}<\mathrm{t}<70$ '; intermediate $20^{\prime}<\mathrm{t}<40^{\prime}$. To calculate this indicator time it has been used the methodology of territorial DPS-DUVAL, using an indicator of accessibility calculated in minutes of distance to the pole closest [5]. The programming of European Community Funds 2014-2020 provides the opportunity to formulate a strategy that, starting from current initiatives, public and private, and uniting with national policies, give force and effect, even beyond 2020, again with particular attention to the contexts territorial.

In relation to the latter, this paper proposes a reflection on the inland areas of south-central Sicily, particularly the Agrigento Province [Fig. 1].

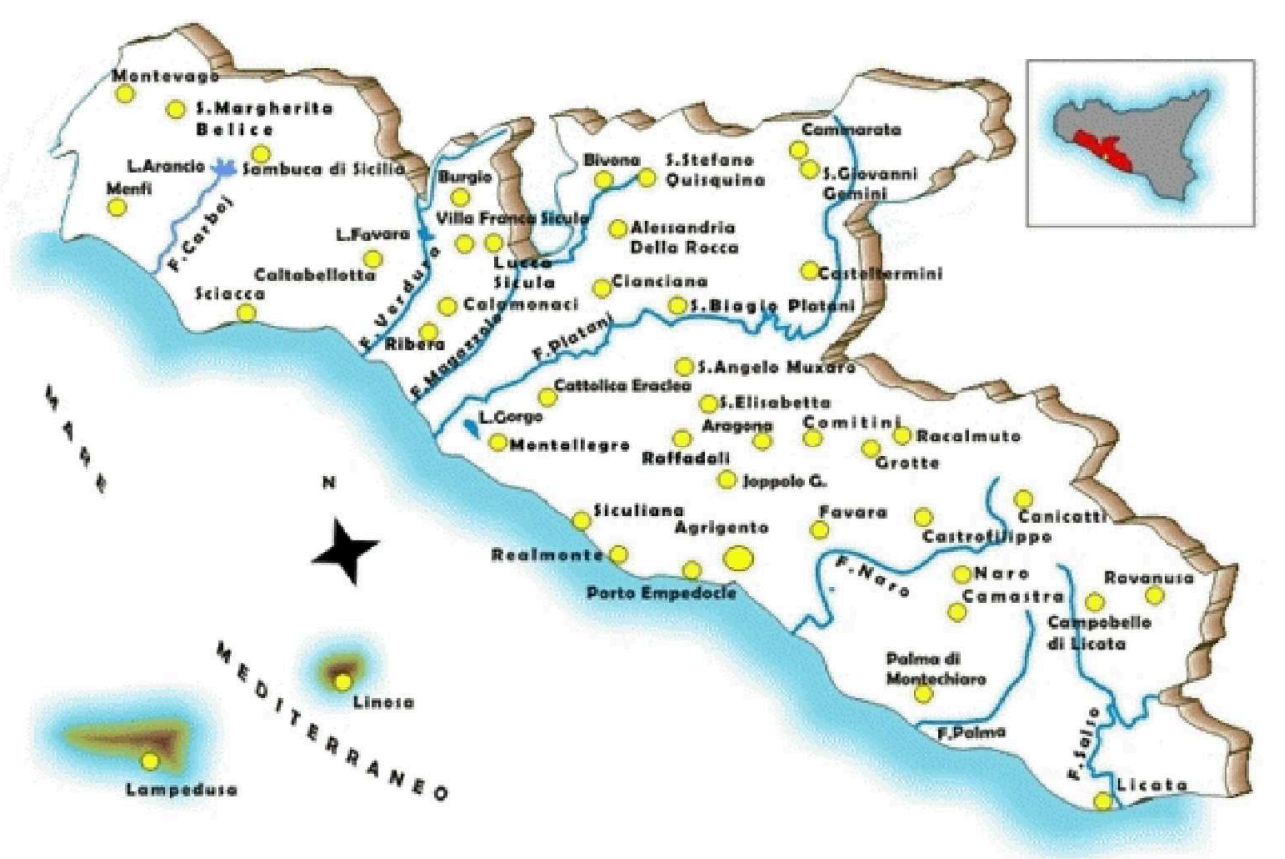

Fig. 1. Agrigento Province. (by http://img212.imageshack.us/img212/7210/atoey2.jpg)

In Sicily, the small cities (204 out of a total of 390) are located, mostly, in the inland, hilly or mountainous areas, where live, again, abandonment, isolation and fragmentation, unlike the coastal urban area, more dynamic, includes the metropolitan areas and the most important cities. The issues raised are counterbalanced by a sustainable dimension, an agrarian landscape, often, still untouched, absence of noise and air pollution, a dimension with a strong narrative power. Just because them have been progressively abandoned, them have kept fairly complements its urban structure and were (especially in mountain areas) barerly touched by illegal building, a phenomenon that has mainly devastated coastal regions [6].

The choice of Sicily is motivated by several reasons. Sicily is one of the regions receiving the Convergence Objective-together in Campania, Puglia, Calabria-aimed at speeding up the convergence of the Member States and regions lagging behind in development in order to improve the conditions for growth and employment. In this direction, we work through the quality of investment, innovation and the development of the knowledge society, the protection and improvement of the quality of the environment and administrative efficiency. In the classification of the residents in the inland areas, Sicily is the fifth largest (after Basilicata, Trentino Alto Adige, 
Sardinia and Calabria), with $42.7 \%$ of the total population and the percentage of land area of the municipalities of inland areas is equal $75 \%(19,330$ out of a total of $25,711 \mathrm{sq} \mathrm{km})$ [7].

Furthermore, in the eighties, a regional law (LR 26/1988) on Measures for the development of inland areas, the letter. c) of art. 2, pointed to with inland areas, the territories of the municipalities falling in whole or in part in less-favored areas and areas covered by the program to combat poverty. The mainly negative meaning of this definition contrasts with the positive value that currently it is proposed to allocate not identify internal area as weak area.

In this context, we examined the case of the region in Agrigento: the 42 municipalities that make up the province of Agrigento, 8 fall into the category centers (Agrigento is the pole) and Area 34 are inland ( 5 of which the outermost, 16 peripheral and 23 intermediate).

The present study was conducted on all municipalities but not on those outermost and peripheral areas (21) which are more distant from the pole and longer subject to the problems typical of these areas (population decline, unemployment, lack of services). Furthermore, it is particularly interesting to deal in one of the poorest provinces of Italy presented (excluding the three metropolitan areas of the island) the largest number of municipalities classified as inland areas; these areas are involved in national and Community programs launched in the second half of the nineties which started «a phase of revival of local planning that led to the production / recovery of a systemic dimension between urban centers, production systems, environmental systems and historical»[8].

The tools of this new programming, used by the municipalities of area inside the region of Agrigento are mainly the PIT (Integrated Territorial Project) and the Territorial Pacts [Table 1].

Table 1. Processing of data ISTAT and DPS, by the authors.

\begin{tabular}{|c|c|c|c|c|c|c|}
\hline COMUNE & CLASSE & $\mathrm{Kmq}$ & ABIT. & $\begin{array}{c}\text { Variazione } \\
\text { demografica } \\
2001-2011\end{array}$ & $\begin{array}{c}\text { Variazione \% } \\
\text { imprese locali } \\
2001-2011\end{array}$ & $\begin{array}{c}\text { STRUMENTI DI } \\
\text { PROGRAMMAZIONE }\end{array}$ \\
\hline $\begin{array}{l}\text { Alessandria } \\
\text { della Rocca }\end{array}$ & Ultraperiferico & 61,93 & 3118 & $-42,13 \%$ & $-12 \%$ & PIT Magazzolo-Platani \\
\hline Bivona & Ultraperiferico & 32,05 & 3882 & $-23,07$ & $-4,1 \%$ & PIT Magazzolo-Platani \\
\hline Burgio & Periferico & 42,22 & 2780 & $-25,41$ & $-4,3 \%$ & PIT Magazzolo-Platani \\
\hline Calamonaci & Periferico & 32,56 & 1375 & $-11,8$ & $-19,2 \%$ & Aquae Labodes \\
\hline Caltabellotta & Periferico & 57,10 & 3907 & $-29,3$ & $-12,5 \%$ & Aquae Labodes \\
\hline Cammarata & Periferico & 192,03 & 6267 & $-9,71$ & $-9 \%$ & PIT Magazzolo-Platani \\
\hline $\begin{array}{l}\text { Campobello } \\
\text { di Licata }\end{array}$ & Periferico & 80,90 & 10358 & $-4,87$ & $-42 \%$ & Demetra \\
\hline Casteltermini & Periferico & 99,51 & 8487 & $-20,21$ & $-3 \%$ & PIT Magazzolo-Platani \\
\hline Cianciana & Periferico & 37,70 & 3532 & $-31,39$ & $+23 \%$ & PIT Magazzolo-Platani \\
\hline Lucca Sicula & Ultraperiferico & 18,62 & 1939 & $-36,21$ & $-21 \%$ & PIT Magazzolo-Platani \\
\hline Ravanusa & Periferico & 49,84 & 11941 & $-19,19$ & $+7,5 \%$ & Demetra \\
\hline Ribera & Periferico & 118,71 & 19231 & $+14,65$ & $+3,2 \%$ & Aquae Labodes \\
\hline $\begin{array}{l}\text { Sambuca di } \\
\text { Sicilia }\end{array}$ & Periferico & 95,13 & 6017 & $-15,42$ & $-8 \%$ & Aquae Labodes \\
\hline $\begin{array}{l}\text { San Biagio } \\
\text { Platani }\end{array}$ & Periferico & 42,19 & 3555 & $-33,52$ & $+2 \%$ & PIT Magazzolo-Platani \\
\hline $\begin{array}{l}\text { San Giovanni } \\
\text { Gemini }\end{array}$ & Periferico & 26,30 & 8087 & $+4,50$ & $+10,5 \%$ & PIT Magazzolo-Platani \\
\hline $\begin{array}{l}\text { Santa } \\
\text { Margherita } \\
\text { Belice }\end{array}$ & Periferico & 66,26 & 6647 & $-21,57$ & $+5 \%$ & $\begin{array}{lll}\text { Patto territoriale } & \text { Terre } \\
\text { Sicane } & & \\
\end{array}$ \\
\hline $\begin{array}{l}\text { Sant'Angelo } \\
\text { Muxaro }\end{array}$ & Periferico & 64,55 & 1523 & $-25,52$ & $-9,8 \%$ & PIT Magazzolo-Platani \\
\hline $\begin{array}{l}\text { Santo Stefano } \\
\text { Quisquina }\end{array}$ & Ultraperiferico & 85,92 & 4914 & $-17,03$ & $+10,3 \%$ & PIT Magazzolo-Platani \\
\hline Sciacca & Periferico & 190,30 & 40946 & $+29,46$ & $+15,3 \%$ & Aquae Labodes \\
\hline $\begin{array}{l}\text { Villafranca } \\
\text { Sicula }\end{array}$ & Periferico & 17,53 & 1455 & $-25,46$ & $-15,1 \%$ & PIT Magazzolo-Platani \\
\hline
\end{tabular}

Take action on the connection in order to promote the cohesion in inland area

The table 1 presents a synoptic view of the 21 municipalities under review, assessing - beyond classification (suburban and outermost areas) - the surface, the number of inhabitants, the demographic shift relating to decade from 2001 to 2011, the percentage change in the activity local businesses, the programming tools active. Comparative analysis shows that, in the decade of 
reference, which coincides with the approval of the PIT- Magazzolo-Platani, Demetra, Aquae Labodes- the population has decreased by $-42.13 \%$, as in the case of Alessandria della Rocca, or $36.21 \%$ as in the case of Lucca Sicula. The only areas in which there is a positive trend are Sciacca and Ribera, which - beyond classification suburban area - are an economic hub constantly growing, as evidenced by the data relating to the change of industry workers.

If, elsewhere, dispersion creates disastrous effects in terms of consumption / waste of soil, weld of urban centers, with environmental consequences, in the context of the study, instead, the issues to be addressed relate to the exodus of the population that has reached alarming figures and asks urgent concrete measures.

There is in this region, the need for a systemic view to achieve a «city united in a more elastic way» [9]. The networks are among the factors contributing to the roots of «virtuous circles of development». At the same time, the reinterpretation of mobility and territorial linkages, we can envisage new sustainable and encourage greater territorial cohesion.

If the urban dynamism can also pass through the mobile communication systems and networks, through which one realizes the Network Society [10], the systemic vision outlined here, aims to interconnected networks and integrated into new forms of infrastructures; new forms of spatial organization "of the economy and of information" that "also determine a new organization of services (...) a radical change in thinking about urban space. (...) Growth (...) the city is mostly sustained critical infrastructure "[11].

The vision proposes a multi-layered and multi-dimensional territory characterized by infrastructure networks, networks of settlement, economic and social formations [12], set up with a multi-scale approach as required by the paradigm of sustainability, «a regional strategy for the medium-long-term» and, on the small scale, the answer «to ad hoc needs»[13]. The improvement of accessibility, provision of community facilities and urban services - in terms of network - will bring benefits to the 20 municipalities in question.

The study focused on the solutions that ensure social relations of production and promote the recovery of a dimension of identity over orographic barriers [14], so that cities become «friends» [15] and residents do not leave them. A city that also creates the physical and spacial preconditions [16] for the most vulnerable, the elderly or children to counter discomfort and loneliness. The transport system, integrated and coordinated with the comprehensive regional planning [17] plays a "crucial role" in urban and extra urban sustainability [18]. Mobility is a fundamental component of people's lives, production and distribution of goods, operation of cities and their development [19]. The mobility enabled new forms of urban spatiality and new social behaviors [20]. But to achieve this, it is desirable to ensure that the internal and external connections to the centers identified through a mobility verified with monitoring and evaluation [21]- in order to encourage urbanization lattice, liveable and economically sustainable.

In the case of the region of Agrigento, it is more appropriate deal in about the mobility and not about the transport, to move from a logic of exclusive government of the offer, a demand, through projects and policies that promote use integrated soil, actions to promote intermodality, projects to improve the construction of circuits safe mobility.

This accessibility could be resolved if the services and mobility systems will coexist in intermunicipal cooperation, always desirable. Therefore, in this paper it is proposed, not the construction of new road infrastructure (currently the towns are connected by provincial roads) but the improvement of the track and the management of existing roads. It is proposed to plan a shuttle bus which ensures accessibility to several towns, in a continuous circuit, to gradually discourage the use of private cars in favor of a network based on interchange of different types transport system: public-private and electric-vehicular, favored by special park and ride specially placed.

At the conclusion of these considerations, it would be desirable to rediscover a slow mobility with the use of trazzere (historical, unpaved and narrow roads), alternative routes which would help to start the recovery of a identity dimension. Valuing these paths, which draw the Sicilian rural landscape, would make them an element of connection and not of caesura, while valuing the 
resources scattered throughout the territory, according to the multifunctionality promoted by the EU.

\section{Work Prospects}

During of the new Community measures that promote local development in less favored areas, while recognizing the value of complex programming as a possible element of cohesion and economic recovery, we believe that- in the study area - it has had no desired effect . To start virtuous dynamics of their cooperation, therefore, the contribution aims to intervene with a reticular approach, with a strong identity value, leading to a free physical and virtual so that, combining protection, exploitation of resources, services and economic development, in such small municipalities be returned liveability and attractiveness.

Although sharing of the topics deal in the proposed article, the part with the title Inland areas in the Italian reality: Sicily and the case of Agrigento has been written by Gerlandina Prestia, while the part with the title Take action on the connection in order to promote the cohesion in inland areas and the part with title Work Prospects have been written by Valeria Scavone. The introduction was written by both authors.

\section{References}

[1] Information on http://ec.europa.eu/europe2020/index_it.htm (25/02/2014).

[2] Anci: Atlante dei piccoli comuni (2013).

[3] T. Cannarozzo: Centri storici e città contemporanea.Dinamiche e politiche, in G. Abbate, T. Cannarozzo, G. Trombino, Centri storici e territorio. Il caso Scicli, Firenze, Alinea, (2010), p.7.

[4] M. Carta, Creative city. Dinamic, Innovation, Actions, Barcellona, List (2007).

[5]http://www.dps.gov.it/opencms/export/sites/dps/it/documentazione/ Aree_ interne/ Analisi_ statistiche/ Nota_Territorializzazione_AI_03_marzo_2013.pdf (25/02/2014).

[6] G.Trombino: Le coste, urbanizzazione e abusivismo, sviluppo sostenibile e condoni edilizi, in: M. Savino (a cura di): Pianificazione alla prova del Mezzogiorno, Milano, Franco Angeli (2005).

[7] Cfr. [5]

[8] I.Vinci: Progetto locale e riconfigurazione dei sistemi territoriali in Sicilia, in: F. Lo Piccolo e F. Schilleci (a cura di), A sud di Brobdingnag. L'identità dei luoghi: per uno sviluppo locale auto sostenibile nella Sicilia occidentale, Milano, FrancoAngeli, (2003), pp. 151-187.

[9] A. Petrillo: Villaggi, città, megalopoli, Roma, Carocci editore, (2006).

[10] M. Castelles: The rise of network society, Blackwell, Oxford, (2002).

[11] A. Giuntini: Reti infrastrutture e servizi urbani nelle città italiane in epoca contemporanea, in Storia e Futuro. Rivista di storia e Storiografia, Aprile, n. 4, (2004)

[12] A. Clementi (a cura di): L'armatura infrastrutturale e insediativa del territorio italiano al 2020, Principi, scenari, obiettivi, Rapporto intermedio della Società Italiana degli Urbanisti per il Ministero delle Infrastrutture e dei Trasporti, Dicoter, Roma, 20 febbraio, (2006).

[13] A.L. Palazzo (a cura di): Sostenibilità, efficienza, equità, in: Urbanistica Informazioni, 231, (2010), pp. 9-10. 
[14] F. Lo Piccolo, F. Schilleci: Efficacia della rappresentazione identitaria eco-sostenibile nella pianificazione: compatibilità e conflittualità fra identità dei luoghi e progettualità locale, in: A. Magnaghi (a cura di): La rappresentazione identitaria del territorio. Atlanti, codici, figure, paradigmi per il progetto locale, Alinea Editrice, Firenze, (2005).

[15] G. Amendola: Tra Dedalo ed Icaro. La nuova domanda di città, Bari, Laterza, (2010).

[16] A. Cecchini, V. Talu: Camminare (e pedalare) per trasformare la città, TeMA, 04.11, Napoli, pp.99-108, (2011).

[17] Libro Verde sul Trasporto Urbano, (2007).

[18] R. Camagni: M.C. Gibelli, P. Rigamonti, I costi collettivi della città dispersa, Alinea, Firenze (2002).

[19] A. Fubini: Corridoio politiche e lo sviluppo territoriale. Infrastrutture principali e nodi urbani in corridoio V, FrancoAngeli, Milano, (2008).

[20] Cfr. [12]

[21] C. Socco: Il piano urbano di mobilità sostenibile. Linee d'azione, indicatori e monitoraggio, Alinea Editrice, Firenze, (2009). 